\title{
Physical Exercises cause Muscle Damage and Potential Treatments to Increase Range of Motion
}

\author{
Setya Rahayu ${ }^{1}$, Mohammad Arif $\mathrm{Ali}^{2}$, Natsuangkorn Kongchulagul ${ }^{3}$, \\ Ebenezer Silaban ${ }^{4}$, Didit Prakosa Adi Nugroho ${ }^{5}$, Muchamad Sadhali ${ }^{6}$, \\ Sugiarto $^{7}$, Gustiana Mega Anggita ${ }^{8}$ \\ \{ setyarahayu@ mail.unnes.ac.id ${ }^{1}$, hiarifalikhan@mail.unnes.ac.id ${ }^{2}$, \\ natsuangkorn.ko@ised.tu.ac.th $\left.{ }^{3}\right\}$ \\ Universitas Negeri Semarang, Semarang, Indonesia ${ }^{12}$ \\ Kasetsart University, Bangkok, Thailand ${ }^{3}$
}

\begin{abstract}
Flexibility is one key of physical fitness components, it is quite important to support daily activity and sport performances. This study aims to identify what type of physical exercises induce muscle damage, to evaluate changes in flexibility (ROM), and to identify potential flexibility training. Original studies which no longer than ten years were considered in this study (secondary data), and other significant references also acceptable to support the storylines. The first step was codifying, followed by analysis and synthesis, and last step was conclusion drawing. It must be done sequentially to reveal the reasonable answers. Eccentric muscle contraction, exessive volume, and prolonged duration are factors of training which lead muscle injuries. ROM is decreased due to muscle damage, it last longer in untrained men. Stretching, foam rolling, sport massage, Propioceptive Neuromuschular Facilitation (PNF) are potential flexibility trainings might be able to improve ROM and accelerate healing process in muscle damaged.
\end{abstract}

Keywords: eccentric exercise; range of motion (ROM); muscle health.

\section{Introduction}

Physical exercise is a systematic activity in a certain time with goals setting. Training program in elite sports aims to improve athletes' skills, while in trained people besides exercise as part of their lifestyle, usually it aims to improve overall health status. A training without program is most likely cause injury, while in athletes or trained population injury usually due to excessive or prolonged exercise [1] [2]. The response of our body when getting excessive exercise will stimulate and experience damage to muscle tissue [3]. The occurrence of an inflammatory response is a continuous response to tissue injury by immune system due to injury [4]. Excessive training must be done with a well-designed program. Excessive weight training is provided 
with the aim that physiological functions can adjust to the demands of the functions needed at a high level [5].

Sports injuries are damage that occurs in organs of the body that carry out sport activities. Muscle will suffer injury because of the breakdown of some muscle fibers due to exercise, after a few hours later it will feel muscle aches and can last for several days [6]. Delayet Onset Muscle Soreness (DOMS) is a form of injury, delayed muscle pain that often occurs after training caused by muscle tissue damaged due to performing continuous or too heavy exercise programs. [7]. DOMS is a condition in which pain and discomfort that occurs in nerve muscles, and the metabolic system about 24 hours after exercise, reaches a peak after 24 hours to 72 hours and the effect will gradually disappear after 5-7 days later [8].

Muscle injuries decrease body functions including pain, increased muscle circumference, decreased Range of Motion (ROM), decreased muscle strength, and increased inflammatory response [9][10]11]. ROM can be affected by daily habits such as squatting toilets, sitting cross-legged, squatting, and kneeling. These activities or habits can affect ROM in the hips, knees and ankle joints [12]. Apart from physical activities, decreased ROM occur when the body does not do enough physical activity which causes a decrease in musculoskeletal also called muscle atrophy [13].

According to the elucidation above, the purposes of this study are: 1) to identify what type of physical exercises induce muscle damage, 2) to evaluate changes in flexibility (ROM) during muscle damage, and 3 ) to identify potential flexibility training.

\section{Materials and Methods}

Materials, data in this traditional literature review are secondary. data stations such as Google Scholar, PubMed, ResearchGate, Reports, Blogspots, News Paper, et cetera were being accessed to collect related materials. Original studies which no longer than ten years were considered being used in this survey paper, therefore data are secondary. However, usage of other significant references also acceptable to support the storylines. Twenty-five papers cited in this study, twenty papers $(80 \%)$ were published between years 2010 to 2020; three papers (12\%) year 2008, 2004 and 2001; last two papers (8\%) year 1992 and 1987.

Methods, the first step was codifying (colleting and sorting all related studies from sources). The second was Analysis and Synthesis, in this step data extraction initially performed then followed by detailed examination on how data from chosen materials could be constructed into data interpretation. The last step was the end of literature study process by conclusion drawing. All the steps must be done sequentially in order to reveal the reasonable answers.

\section{Results and Discussion}

\subsection{Eccentric Exercise}

Studies show that eccentric physical exercise is the most accurate causing muscle damage. Eccentric physical exercise particularly in resistance exercise is a training 
which skeletal muscle performing extending contraction (muscle fibers are extended) to produce strength [14]. The modes of eccentric exercise such as uphill and downhill running, long distance running (marathon), and weight lifting [15]. Eccentric muscle contractions with high strength will result in pain and damage to the muscles in a temporary time, evidence of damage is pain due to damaged muscle fibers [16].

Muscle damage as a response of eccentric training contributes to DOMS phenomenon. A shift in optimum length for tension in the direction of longer muscle lengths caused sarcomeres being rapidly, uncontrollably, and repeated overstrecthed beyond myofilament overlap and tension in passive structures. Once the disrupted region getting larger, it leads to membrane damages especially to the sarcoplasmic reticulum. At this stage, exessive $\mathrm{Ca}^{2+}$ release triggering of a local injury contracture. Therefore, muscle passive tension would raise. This damage leads to a local inflammatory response associated with tissue oedema and soreness, (Figure 1).

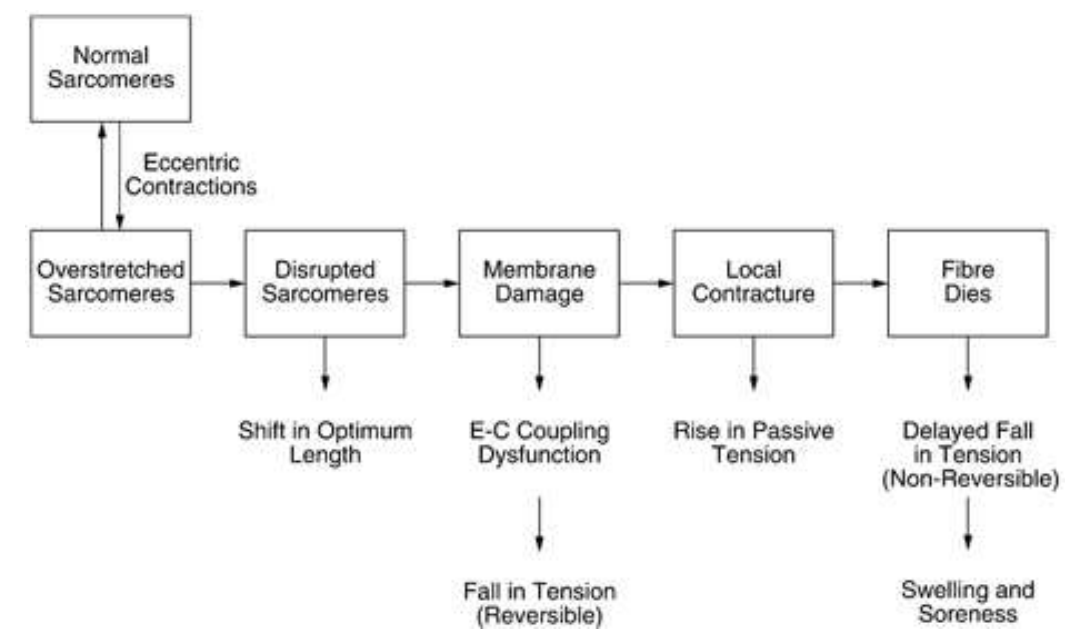

Fig. 1. Eccentric exercise leading to muscle damage. Figure is adopted from Proske U, Morgan DL [17]

Apart from causing muscle injury and tissue damage while doing extrinsic exercises, there are advantages to doing this exercise. Especially weight lifting is very effective for increasing hypertrophy, experiencing more significant developments in muscle size and strength. The body can use much heavier weights (1.75 times heavier than normal weights) in eccentric exercises.

\subsection{ROM responses on muscle damage}

Range of Motion is a movement that under normal circumstances can be carried out by the joint in question. ROM is the standard term for expressing the limit/magnitude of normal good joint motion. ROM is also used as a basis for establishing abnormal joint movement boundaries. In a state of muscle damage, muscles that experience stiffness will experience obstacles when performing scope of joint motion. 
The flexibility of the body is affected by the state of the muscles that are experiencing pain due to eccentric exercise. When the body experiences muscle damage it will affect the scope of joint motion. Muscle damage after physical exercise will induce pain, decreased range of motion (ROM), increased muscle circumference that can damage, and decreased muscle strength [15][10][11].

A comparison study on ROM response between trained men versus untrained men after performing 10 sets of 6 maximal voluntary eccentric actions of the elbow flexors of one arm against the lever arm of an isokinetic dynamometer moving at a constant velocity of $90^{\circ} . \mathrm{s}^{-1}$ shows that eccentric physical exercise directly affecting in both trained and untrained men. However, trained men obviously having light response and recover earlier at the first day post eccentric exercise compared to untrained men, while untrained men were not even return to their baseline until five days post eccentric exercise, (Figure 2).

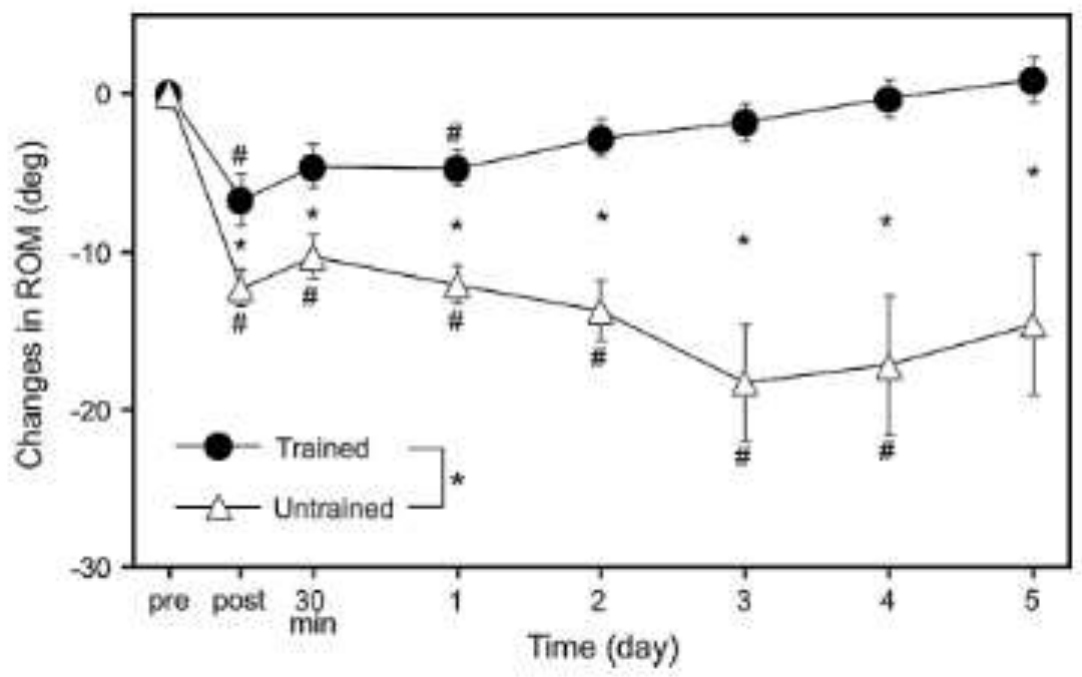

Fig. 2. Changes in ROM from baseline (pre: 0) immediately (post) and 30 minutes after exercise, and 1-5 days after exercise for the trained and untrained groups. *Significantly different between groups (interaction: $\mathrm{P}, 0.05$, each time point: $\mathrm{P}, 0.007$ ), \#Significantly different from pre-exercise value. Figure is adopted from Newton MJ, Morgan GT, Sacco P, Chapman DW, Nosaka K., 2008. [18]

\subsection{Flexibility exercises as treatment on musle damage}

Flexibility is an important part in various sports [19]. Flexibility is the ability to make movements in the joint motion by being affected by the elasticity of muscles, tendons, and ligaments. Physical activity, obesity, age, gender, bone structure, muscle, joint size, and connective tissue around the joints are determinants of flexibility [20]. The design and various exercises to increase body flexibility vary according to the goals and areas to be improved, whether it is upper extremity or lower extremity. 
Stretching has an important role in the treatment of damaged soft tissue. When a muscle experiences strain due to exercise, stretching usually being used as a method of recovering the muscular system including tendon or after acute trauma. it is used to treat over-strained muscles and for relaxation [21]. Especially static stretching is recommended as a way to prepare muscle groups at the beginning of endurance training, because it is believed that this type of stretching can prevent DOMS.

Foam roller is a recovery tool which is used after physical exercise to correct muscle imbalance, reduce muscle pain, reduce joint stress, neuromuscular efficiency, and increase ROM. Foam rolling usually performed for recovery after exercise. Foam rolling can reduce muscle pain. Foam rolling is also believed able to improve muscle imbalance, reduce muscle pain, increase ROM and coordination, improve neuromuscular efficiency, and help reduce stress on joint motion [8][22]. When it is used as a tool to warm up before physical exercise, it can inreased flexibility [19].

A study conduted by Macdonald Graham Z. showed that self-myofascial release using foam roller has significant effect on improving ROM. It is significantly increased $12.7 \%$ at 2 minutes and $10.3 \%$ at 10 minutes respectively post foam rolling compared to control group who did not use foam roller, (Figure 3 ).

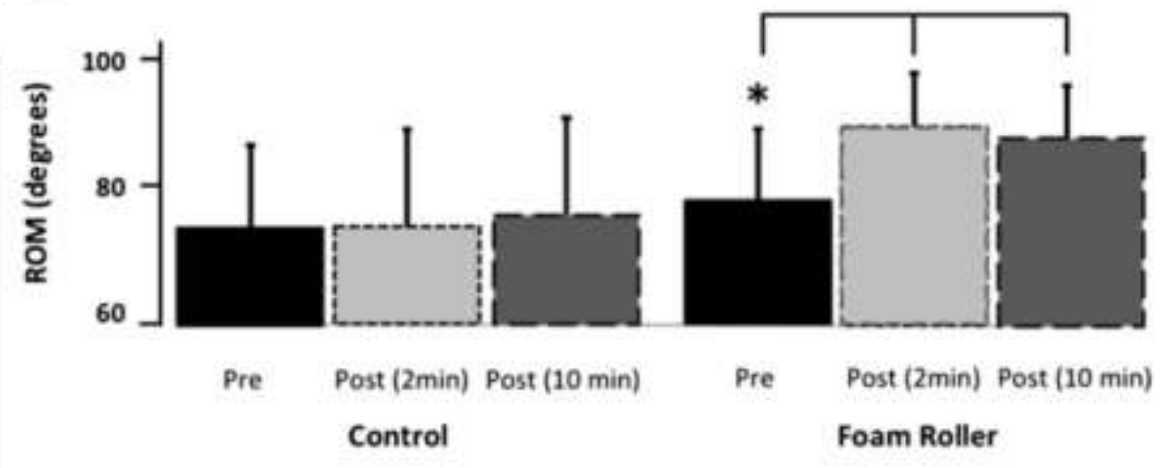

Fig. 3. Knee joint ROM did not change in the control condition but significantly increased after foam rolling. * Represents a statistical significance at $P<0.001$. All data are presented as mean \pm SD. Figure is adopted from Macdonald Graham Z., 2013. [22].

Sport massage treatment after a long period of competition or working with short break, it can be an alternative to relieve the feeling of a raft, including when the body experiences a muscle damage grade I. Sport massage can help in increasing flexibility. additionally, the manipulation of sport massage with its application can reduce the tension of non-active muscle antagonists [23].

Propioceptive Neuromuschular Facilitation (PNF) is another form of flexibility exercise. PNF stretching training technique is a therapy by providing stimulus to proprioceptors as a easier way to increase the need for mechanisms of neuromuscular system [24]. This method seeks to provide stimuli according to expected reactions, which in turn will be achieved ability or movement that is coordinated. PNF will strengthened and intensified specific stimuli through joint receptors (proprioceptive). Neuromuscular, also increases the response of the neuromuscular system [25]. 


\section{Conclusion}

Exercises which involved eccentric muscle contraction, exessive volume, and prolonged duration are types of training with high risk of injuries. Range of Motion is decreased due to muscle damage, and it last longer in untrained than in trained men. Stretching, foam rolling, sports massage, and Propioceptive Neuromuschular Facilitation (PNF) are considered as potential flexibility trainings which might be could improve ROM and accelerate the healing process in muscle damage.

\section{Acknowledgments}

This study is part of an investigation about effects of high density foam roller on blood lactate and range of motion as indicators of delayed-onset muscle soreness (DOMS) post long distance running in trained young males. This study was granted by Research and Community Services Institute of UNNES/Lembaga Penelitian dan Pengabdian kepada Masyarakat, Universitas Negeri Semarang (DIPA UNNES Tahun Anggaran 2020. Nomor Surat Perjanjian Penugasan: 234.23.4/UN37/PPK.3.1/2020).

\section{References}

[1] A. Setiawan, Factors for Sports Injuries. "Faktor Timbulnya Cedera Olahraga," J. Media Ilmu Keolahragaan Indones., vol. 1, no. 1, 2011.

[2] F. P. Sastra, .Differences in the Effect of Kinesio Taping Hamstring on Pain Reduction during Delay Onset Muscle Soreness ( Doms ). "Perbedaan Pengaruh Pemberian Kinesio Taping Hamstring Terhadap Penurunan Nyeri Saat Kejadian Delay Onset Muscle Soreness ( Doms )," Universitas Muhammadiyah Surakarta, 2018.

[3] D. Z. Sidik, Principles Of Training Principles In Sports Achievements. "Prinsip Prinsip Latihan Dalam Olahraga Prestasi," pp. 1-8, 2010.

[4] S. Sari, vercome Doms After Sports. "Mengatasi Doms Setelah Olahraga," Motion, vol. 7, no. 1, pp. 97-107, 2016.S

[5] Y. O. Seneva, The Effect Of Load Training Method Of Circuit Strength Muscle Strength In Fc Uny Players In Facing Around Around Years 2018. "Pengaruh Latihan Beban Metode Circuit Kekuatan Otot Tungkai Pada Pemain Fc Uny Dalam Menghadapi Liga Nusantara Tahun 2018," Universitas Negeri Yogyakarta, 2018.

[6] A. S. Graha, Benefits Rest In Post Of Injuries Due To Sports. "Manfaat Istirahat Pada Pasca Cedera Akibat Berolahraga," MEDIKORA, vol. 18, no. 1, pp. 49-55, Dec. 2019.

[7] H. S. Lesmana, rofile Of Delayed Onset Muscle Soreness (Doms) In Fik Unp Students After Physical Training. "Profil DELAYED ONSET MUSCLE SORENESS (DOMS) Pada Mahasiswa FIK UNP Setelah Latihan Fisik," Hal. Olahraga Nusant., vol. 2, pp. 196, 2019.

[8] G. E. P. Pearcey, D. J. Bradbury-Squires, J. E. Kawamoto, E. J. Drinkwater, D. G. Behm, and D. C. Button, "Foam rolling for delayed-onset muscle soreness and recovery of dynamic performance measures," J. Athl. Train., vol. 50, no. 1, pp. 5-13, 2015.

[9] R. G. Eston, G. Gleim, M. P. Mchugh, D. A. J. Connolly, R. G. Eston, and G. W. Gleim, "Exercise-Induced Muscle Damage and Potential Mechanisms for the Repeated Bout Effect Exercise-Induced Muscle Damage and Potential Mechanisms for the Repeated Bout Effect," vol. 27, no. July, pp. 157-170, 2014. 
[10] E. C. D. Burnley, A. N. Olson, R. L. Sharp, S. M. Baier, and D. L. Alekel, "Impact of Protein Supplements on Muscle Recovery After Exercise-induced Muscle Soreness," $J$. Exerc. Sci. Fit., vol. 8, no. 2, pp. 89-96, 2010.

[11] C. R. Denegar and D. H. Perrin, "Effect of transcutaneous electrical nerve stimulation, cold, and a combination treatment on pain, decreased range of motion, and strength loss associated with delayed onset muscle soreness.," J. Athl. Train., vol. 27, no. 3, pp. 200206, 1992.

[12] H. Hallaçeli et al., "Normal hip, knee and ankle range of motion in the Turkish population," Acta Orthop. Traumatol. Turc., vol. 48, no. 1, pp. 37-42, 2014.

[13] U. Sarah and S. Bambang, Influence of Range of Motion (ROM) Exercise on Knee Joint Flexibility in the Elderly at Wardoyo Weda Wardoyo Ungaran. "Pengaruh Latihan Range of Motion (Rom) Terhadap Fleksibilitas Sendi Lutut Pada Lansia Di Panti Wreda Wening Wardoyo Ungaran," Nurse Media J. Nurs., vol. 1, no. 2, pp. 72-78, 2010.

[14] Athanasios Z. Jamurtas. Ioannis G. Fatouros, "Eccentric Exercise, Muscle Damage and Oxidative Stress," An Int. Perspect. Top. Sport. Med. Sport. Inj., 2012.

[15] R. Eston, C. Byrne, and C. Twist, "Muscle function after exercise-induced muscle damage: Considerations for athletic performance in children and adults," J. Exerc. Sci. Fit., vol. 1, no. 2, pp. 85-86, 2004.

[16] D. J. Newham, D. A. Jones, and P. M. Clarkson, "Repeated high-force eccentric exercise: Effects on muscle pain and damage," J. Appl. Physiol., vol. 63, no. 4, pp. 1381-1386, 1987.

[17] U. Proske and D. L. Morgan, "Muscle damage from eccentric exercise: mechanism, mechanical signs, adaptation and clinical applications," J. Physiol., vol. 537, no. 2, pp. 333-345, Dec. 2001.

[18] M. J. Newton, G. T. Morgan, P. Sacco, D. W. Chapman, and K. Nosaka, "Comparison of responses to strenuous eccentric exercise of the elbow flexors between resistance-trained and untrained men," J. Strength Cond. Res., vol. 22, no. 2, pp. 597-607, 2008.

[19] C. A. Peacock, D. D. Krein, T. A. Silver, G. J. Sanders, and K.-P. A. VON Carlowitz, "An Acute Bout of Self-Myofascial Release in the Form of Foam Rolling Improves Performance Testing.," Int. J. Exerc. Sci., vol. 7, no. 3, pp. 202-211, 2014.

[20] F. Az-zahra, Nastiti dan Ichsani, Contract Relax Stretching Is More Effectively Improve The Flexibility Of Muscle Hamstring Compared To Passive Stretching In The Taxwondo Club Underdog Athlete. "Efektivitas Antara Latihan Kontraksi Eksentrik Hydroterapy Dengan Latihan Ballistic Stretching," J. Fisioter., vol. 16, no. 1, 2016.

[21] A. Wiguna, D. Silakarma, and R. Sundari, "Contract Relax Stretching Lebih Efektif Meningkatkan Fleksibilitas Otot Hamstring Dibandingkan Dengan Passive Stretching Pada Atlet Underdog Taekwondo Club," vol. 000, pp. 1-13, 2014.

[22] graham z. Macdonald, "An Acute Bout Of Self-Myofascial Release Increases Range Of Motion Without A Subsequent Decrease In Muscle Activation Or Force," J. Strength Cond. Res., pp. 812-821, 2013.

[23] A. Mostafaloo, "The effect of one session massage in the lower limb muscle on flexibility, power and agility tests performance in soccer players," Pars Jahrom Univ. Med. Sci., vol. 10, no. 2, pp. 17-24, 2012.

[24] S. Alfarisi, Influence of PNF (Proprioceptive Neuromuscular Facilitation) and Thai Massage Exercises on the Level of Flexibility of the Uky Karate Inkai Athletes Uny. "Pengaruh Latihan Pnf (Propioceptive Neuromuschular Facilitation) Dan Thai Massage Terhadap Tingkat Fleksibilitas Togok Atlet Ukm Karate Inkai Uny," vol. 2, pp. 6-11, 2018.

[25] A. Alim, Flexibility Training with the PNF Method. "Latihan Fleksibilitas dengan Metode PNF," Artik. e-staff FIK UNY, pp. 1-9, 2012. 